\title{
DEATH: BORDER OR MEMBRANE? Ascetic-eschatological Dimension of Consecrated Life as 3D Transformation
}

\author{
Krista Mijatović
}

UDK 2-186

$27-558.3$

27-585:2-175

\section{Introduction}

The term of a border does not have to be understood only in terms of space. Borders are also possible in the time dimension. Still, mostly we talk about borders within time-space coordinates. Also, borders are not necessarily static. Borders can be very dynamic and very fluid like cell membranes. Paradoxically, as much as borders separate, on the one hand, they also bind on the other. Death is one of such borders. It is where the two worlds are 'in touch'.

In the first part of this article, there are some reflections on the phenomenon of death in the cultural context and in the light of faith. The issue of the article's second part is a $3 D^{1}$ transformation in consecrated life where $3 D$ means three deaths (baptism, religious consecration and physical death). The framework of developing reflection is Gennep's and Bloch's ideas of rites of passage and ritual death. Their ideas are expanded and applied on consecrated life, especially on its ascetic dimension. Eschatological dimension is a theme of the last section of the article where the asceticism of consecrated people is connected with anticipation of eschaton in such intensive way that convents could be named as heavenly embassies.

\section{Death - a Membrane Between Time and Eternity}

In the cross-cultural perspective, it is possible to notice different approaches to the perception of death. Also, depending on the context of the sociohistorical period, the idea of death has acquired different characteristics.

\footnotetext{
* s. Krista Mijatović, Katolički bogoslovni fakultet Sveučilišta u Zagrebu, kristamijatovic@ gmail.com

1 In the English language it can be nicely said $-3 D$ because it‘s about three deaths (first letter of noun "death“ is D).
} 
Still, all of the understandings contain one constant element; death is the inevitable reality that every human being has to confront. Within death, the man reveals his own limits and the limitations of his own humanity. Furthermore, it seems that the contemporary man considers death to be "his biggest limitation“2

The attitude of the modern society toward death is ambivalent. The man would preferably banish death from the coordinate system of space and time, he would peel off life from death. For the contemporary man death is an undesirable epilogue of a lifetime, a threat he would intensely like to eliminate. Thereby, most often, death is not perceived to be one of the threads present in the weft of life fabric from the very beginning of life, but as a phenomenon that in a certain moment comes from the outside and stops the weaver's mechanism. On the one hand, in the modern society, death is understood as something what could be ordered: e.g. abortion, euthanasia, suicide, terrorism, etc. On the other hand there are attempts to keep death within 'space bounds' by giving it freedom only within some specialized institutions: hospitals, nursing-homes and hospices, where people who are about to die are accommodated. Still, in spite of all the attempts to ghettoize death, it remains out of human control. Although it cannot be eradicated from the course of existence, it exceeds the earthly reality a great deal.

The reflection on death depends, of course, a great deal on the scientific discipline within which the thinking about death is elaborated. Medical sciences, for example, throw different light to the face of death than theological sciences. Even within theological sciences, there are different approaches to the death, in the light of its own specific object of research. While moral theology, for example, has focused on a moral evaluation of human actions concerning death, eschatology oversteps the gap of the grave mound and from its 'other side' answers the questions of the afterlife. From this point of view, in the light of eschatology, death seems to be neither the end of life nor the impenetrable border where every kind of liveliness has no other choice but to give in. In the light of eschatology, death is a fluid-binding border between time and eternity, between heaven and earth. The appearance of death is literally the fluid boundary between heavenly eternity and temporal earth. Death occurs within space-time dimensions, yet it also transcends them.

This very characteristic of fluidity and presence in and above time may be the reason why, in the context of faith, it can be said that death is not a border, but a membrane ${ }^{3}$. The membrane which binds, and not only separates the two worlds. 


\section{3D Transformation}

If death is a membrane between time and eternity, on that membrane could be only somebody who is in a permanent condition of death. Could it be said that consecrated people are in a permanent condition of dying? Permanent condition of dying is, in other words, a sort of transformation. Namely, death is an event that radically changes (transforms) a man's condition, social status and personal identity. To put it picturesquely, consecrated people go through a $3 D$ transformation. To be more precise, it is about going through a triple membrane, or through the three deaths $(3 D)$, in physical and in ritual meaning.

About 'ritual death' wrote an anthropologist Arnold van Gennep (1873 - 1957) and Maurice Bloch. Gennep created the phrase 'status passage rituals". In his book "The Rites of Passage" ${ }^{4}$ Gennep elaborated the idea of the so-called 'border-crossings' crisis situations by which he understands the events in life when an individual, in a certain period of time, moves from one social position/status to another. Among others, Gennep included there: birth, different forms of initiation and death. ${ }^{5}$ Gennep offers a systematic analysis of rites accompanying the 'transitional' life events, emphasizing their social aspect. According to Gennep, there are three phases in every rite: separation, transition and incorporation. ${ }^{6}$ Going through these three phases, a person changes the social status, but also, in a way, the personal identity "because the term identity embraces social and psychological aspects of life" $"$.

Yet, in the terms of a ritual, the change of the identity is not possible without dying. "For there to be a new self the old self must ritually die. Candidates for some rite would be separated from the status to be left behind, leaving familiar companions, surroundings and home. [...] Second, they enter a 'between' period devoid of distinguishing marks of status and expressions of their old identity, such as names or clothing. [...] After [...] period of learning and endurance is complete do they undergo the third phase of reincorporation into society. However, they do so with their new status and identity, perhaps involving a new name or title, forms of dress or style of language and, almost certainly, new patterns of behaviour with appropriate duties and responsibilities."8

4 Cf. Arnold van GENNEP, The Rites of Passage, Chicago, 1960.

5 Cf. Ibid, 3.

6 Cf. Ibid, 11.

7 Douglas J. DAVIES, Rites of Passage, in: Robert KASTENBAUM (ed.), Encyclopedia of Death and Dying II, New York, 2003., 723.

8 Ibid, 724. 
Maurice Bloch developed Gennep's ideas. " facts of life in terms of people being born, maturing, and then dying. Most human cultures, however, are unhappy with this simple progression. Through ritual forms, they take living people and in a symbolic sense cause them to 'die' and be 'reborn' as new kinds of individuals, shedding old, used-up selves so new ones can take their place. Not only are they given a new status but they will also have experienced inner changes to their sense of identity. Many rituals of initiation in religions as well as in some secret societies use the natural idioms of birth and death but reverse them to speak of death and rebirth. It is as though the ordinariness of human nature is „killed“ and a new and higher nature is bestowed. In some religious traditions, this scheme of rebounding conquest can be applied to death rites when physical death is said to be the basis for a new and spiritual life either in future transmigration of the soul or in some form of resurrection." 10

In the context of the rites of passage, it is necessary to emphasize that Christianity "does not only know the rites of passage — the sacraments of Christian initiation but also that the whole entity of Christian rites is imbued by the dimension of initiation"11. And while Gennep, in order to illustrate 'passages' from one state into the other uses the image of 'threshold"12, this article uses the term of 'death' in order to describe a lifelong 'state of transition' which is the only one appropriate to make eschaton present in this world. The threshold is usually used as a passage, but also as a transition. The same can be applied to the death. Death too is a place of both passage and transition. But life as well, in the light of death, does not only seem to be passing, but transitory, too. ${ }^{13}$ On the membranes of the $3 D$ transformation, consecrated people make this world slightly open the door to the other side and eschaton anticipating passes to this side.

Although death is being observed in three different moments of human life (baptism, consecration sacred vows and funeral rites), we are still talking about a single death beginning with baptism, intensifying in consecration and being completed in the last breath, that is at the moment of dying. Obviously, it is a lasting lifelong process, not a one-time moment of human exist-

$$
\text { pre }
$$
of a ritual, the preliminal, liminal, or postliminal phase would be stressed over and above the others." (Douglas J. DAVIES, Rites of Passage, in: Robert KASTENBAUM (ed.), Encyclopedia of Death and Dying II, 724.)

13 Cf. Ante CRNČEVIĆ, Zastati pred vratima crkve, in: Živo vrelo, 32 (2015.) 6, 1. 
ence. Therefore it is maybe more convenient to talk about dying (process), than about death (the outcome of dying). ${ }^{14}$

\subsection{The First Death (Baptism)}

The first death has to do with the sacrament of baptism. The rite of the baptism immersion symbolically represents the death and the grave. By immersion in the water, which is not an existential ambience for a human being occurs the death of the old man, that is, dying to the $\sin .{ }^{15}$ Surfacing, out of the water comes the new man, free from the slavery of sin. Saint Paul ${ }^{16}$ says it well in the Epistle to the Romans: "Or don't you know that all of us who were baptized into Christ Jesus were baptized into his death? We were therefore buried with him through baptism into death in order that, just as Christ was raised from the dead through the glory of the Father, we too may live a new life." (Rom 6: 3-4). The syntagm 'a new life' contains an eschatological value. It should be viewed within 'yes already — not yet' dynamics. It is both reality and an assignment. By baptism believers develop the most intimate connection with Christ, they are crucified, dead and buried with him. The consequence of this connection is the freedom from the power of sin, the old man and death. Although mortal body with its lusts tries to return its snatched away throne to sin, believers are dead when it comes to sin. They are invited to walk in the new life with Christ. The bath of baptism is therefore like a membrane passed by those who decide "to experience sacramentally, with Christ, the spiritual death and the spiritual resurrection" ${ }^{\text {" }}$. Consequently, it could be said that baptism is the first death for the one who starts the road of dying of the old man.

\subsection{The Second Death (Consecrated Life)}

Talking about the second death in the life of religious orders means talking about its ascetic and eschatological dimension. They are both interwoven that much, that it is impossible to mention one without the other. Wherever there is asceticism in the consecrated life, there is also the anticipation of the eschaton, and vice versa, wherever you can find a trace of the eschaton,

Cf. Robert KASTENBAUM, The Good Death, in: Robert KASTENBAUM (ed.), Encyclopedia of Death and Dying, in: http://www.deathreference.com/Gi-Ho/Good-Death-the.html (accessed: 21. X. 2017.)

15 St. Gregory of Nazianzus says that sin is buried in the water. (cf. Grgur NAZIJANSKI, Orationes, 40,3-4; CCC, 1216.)

16 The idea about baptism like being buried with Christ, Paul developed in Epistle to Colossians. (cf. Col 2:12)

17 Martin KIRIGIN, Konstitucija o svetoj liturgiji, Zagreb, 1985., 298. 
it is inevitable asceticism had been practised before. In other words, in the life of religious orders eschaton just passes the well-trodden path of asceticism. Asceticism again includes everything that the life of religious orders is. Eschaton too. It is impossible for this article to illustrate all the pores of life of religious orders that asceticism and eschaton inhabit. Only the most important will be presented: religious consecration, evangelical counsels and religious community life.

\section{a) Religious Consecration}

The second death, characteristic of the consecrated people is, first of all, the moment of consecration through sacred vows. The rite of taking religious vows should be understood in comparison to the sacrament of baptism. In both cases we talk about an initiation (into religious life and into Christianity) and many analogies can be drawn between them. ${ }^{18}$ There are many symbols of baptism hidden in the ritual of religious consecration. Compared to the ritual gesture of dying present in baptism in the act of descent into the baptismal font, in the rite of religious vows the vower "prostrates himself before the community"19.

It is important to notice that the consecration (religious profession) is the act of "a total consecration to God, who alone is worthy of such a sweeping gift on the part of a human person" 20 . To be more precise, "the vow is the most beautiful offertory one can imagine. The man is bringing himself to the altar, climbing the altar together with Christ and dying with him“21. But the consecration is not exhausted in one moment, it is extended to the whole existence. That's why it is proper to say that consecrated people are in the permanent condition of dying.

By living the life after evangelical counsels people in religious orders live the baptism consecration in a more radical way which enables them to incarnate the eschaton symbolism. The fact is that the consecrated life has something in itself that cannot be fully explained by nature, something that goes beyond human logic and the structure of human syllogism; it has 'something transcendental'. Because of 'something transcendental' in religious orders, consecrated people could be named as 'icons of transcendence'. 'Something transcendental' is often hidden, not in the work the consecrated gije redovničkoga zavjetovanja, in: Živo vrelo, 32 (2015.) 2, 11.

19 Ibid.

20 SACRED CONGREGATION FOR RELIGIOUS AND SECULAR INSTITUTES, Renovationis Causam. Instruction on the Renewal of Religious Formation (6. I. 1969.), 2, in: http://www. ewtn.com/library/CURIA/CICLRNEW.HTM (accessed: 21. VIII. 2017.)

21 Martin KIRIGIN, Konstitucija o svetoj liturgiji, 295. 
persons do, but in the mere existence and the witness of the consecrated life in itself.

\section{b) Evangelical Counsels}

Eschatological aspect of consecrated life is closely related to its ascetic dimension because pointing to God requires a lifestyle in which "the fullness of life is acquired by dying that is 'losing" (Mark 8:35)“22. The evangelical counsels of poverty, chastity and obedience present therefore in a certain way space-time membranes where mortality is transformed into eternity.

Namely, according to Hans Urs von Balthasar, by the vow of poverty consecrated people give up and at the same time are freed from the outer material world. The vow of chastity liberates them from their own body and by the vow of obedience they are liberated from their inner world. ${ }^{23}$ It is important to notice that the vows are in contradiction to the values of the modern society. According to the document Starting afresh from Christ, "a life transformed by the evangelical counsels becomes a prophetic and silent witness and at the same time an eloquent protest against an inhuman world" 24 . The vows oppose "greed, the craving of pleasure, the idolatry of power, the triple concupiscence which marks history and is also at the root of present evils" 25 . The evangelical counsels are "a powerful antidote to the pollution of spirit, life and culture; they proclaim the liberty of the children of God and the joy of living according to the evangelical beatitudes" 26 . In short, authentic living after evangelical counsels in community, is in total opposition to contemporary hedonism, individualism, absolutism of liberty and materialism, and precisely because of that contradiction, consecrated life is the membrane of eternity.

Namely, life after evangelical counsels is the life "of renunciation of goods that undoubtedly deserve to be highly valued“"27, like marriage, family,

22 Ozana KRAJAČIĆ, Pozitivni vid odricanja u redovničkom odgoju, in: Posvećeni život, 5 (2001.) 1, 97.

23 Cf. Hans Urs VON BALTHASAR, Za Boga pripravan život. Laik i stalež evanđeoskih savjetâ. Nasljedovanje Krista u današnjem svijetu, Zagreb, 2010., 187.

24 CONGREGATION FOR INSTITUTES OF CONSECRATED LIFE AND SOCIETIES OF APOSTOLIC LIFE, Starting Afresh from Christ. A Renewed Commitment to Consecrated Life in the Third Millennium (19. V. 2002.), 33, in: http://www.vatican.va/roman_curia/congregations/ccscrlife/documents/rc_con_ccscrlife_doc_20020614_ripartire-da-cristo_en.html (accessed: 19. VIII. 2017.)

25 Ibid, 45.

26 Ibid, 13.

27 SECOND VATICAN COUNCIL, Lumen Gentium. Dogmatic Constitution on the Church (21. XI. 1964.), 46, in: http://www.vatican.va/archive/hist_councils/ii_vatican_council/documents/vat-ii_const_19641121_lumen-gentium_en. html (accessed: 19. VIII. 2017.). Further: LG. 
managing material goods and making independent decisions about yourself. So "the vow of obedience is opposed to understading a human being as a being rooted in decisive autonomy and individualism. Being poor in our culture is a sign of failure and insignificancy and chastity seems to be the inconcivable rejection of the universal human right of sexual fulfillment" 28 . However, the vows are not denial of these goods, but only their relativisation in order to proclaim God as absolute good..$^{29}$ That proclamation requires some kind of paschal ${ }^{30}$ experience, some kind of kenosis. In short, it requires ascetic way of living. According to many great teachers of consecrated life (St. Basil the Great, St. Francis of Assisi, St. Ignatius, St. Therese of Avila, etc.) asceticism is very important in life of the consecrated person. For example, St. Basil the Great in sixth quaestion of his Rule is talking about how consecrated person should overcome his own habits ${ }^{31}$, and St. Francis in his Rule said that consecrated life is "life of penance“32. Speech about asceticism (sacrifice ${ }^{33}$, renunciation ${ }^{34}$, penance ${ }^{35}$, discipline) is not inappropriate for today. "Ascetic dimension of religious life is not outdated, but still very important and necessary." 36

\section{c) Religious Community Life}

Life in the community seems to be impossible without asceticism. Indeed, "communion does not exist without the self-offering of each member" 37 . Re-

28 Timothy RADCLIFFE, Redovnici, jeste li sretni?, Zagreb, 2001., 23.

29 Cf. Valentina MANDARIĆ, Redovništvo kao znak i izazov za današnje mlade, in: Bogoslovska smotra, 73 (2003.) 4, 808.

30 Cf. Ibid, 24.; cf. KONGREGACIJA ZA USTANOVE POSVEĆENOG ŽIVOTA I DRUŽBE APOSTOLSKOG ŽIVOTA, Kontemplirajte. Bogu posvećenim muškarcima i ženama na tragovima Ljepote, (15. X. 2015.), Zagreb, 2016., 49.

31 Cf. Bazilije VELIKI, Opširna pravila u pitanju i odgovoru, 6, in: Hadrijan BORAK (ed.), Redovnička pravila, Zagreb, 1985.

32 Franjo ASIŠKI, Pravilo trećeg samostanskog reda sv. Franje, II, 6, in: MILOSRDNE SESTRE SV. KRIŽA, Uredbe za život Milosrdnih sestara svetoga Križa, Đakovo, 1987.

33 Cf. PAUL VI., Evangelica Testificatio. Apostolic Exhortation on the Renewal of the Religious Life according to the Teaching of the Second Vatican Council (29. VI. 1971.), 49, in: http:// w2.vatican.va/content/paul-vi/en/apost_exhortations/documents/hf_p-vi_exh_19710629_ evangelica-testificatio.html (accessed: 19. VIII. 2017.). Further: ET.

34 Cf. PC, 5. and ET, 29.

35 Cf. SECOND VATICAN COUNCIL, Christus Dominus. Decree Concerning the Pastoral Office of Bishops in the Church, (28. X. 1965.), 33, in: http://www.vatican.va/archive/hist_councils/ii_vatican_council/documents/vat-ii_decree_19651028_christus-dominus_en.html (accessed: 19. VIII. 2017.)

36 Ozana KRAJAČIĆ, Pozitivni vid odricanja u redovničkom odgoju, 98.

37 CONGREGATION FOR INSTITUTES OF CONSECRATED LIFE AND SOCIETIES OF APOSTOLIC LIFE, Fraternal Life in Community (2. II. 1994.), 24, in: http://www.vatican.va/ 
ligious community demands accepting others with their limits, overcoming selfish wishes, a lot of effort in self-renunciation. That's why, besides vows, life in the community is also one of the membrane-bonds with eschaton. According to Vita consecrata, "the fraternal life is itself prophetic" ${ }^{38}$ because it represents the unity the Church tends to reach the final goal. Common life is also a sign of communion in the Trinity. ${ }^{39}$

Of course, the asceticism is not the only effort. The asceticism is on a deeper level a joy because it is in service of the eschaton. So, Evangelica testificatio encourages us: 'Let the Cross be for you, as it was for Christ, proof of the greatest love. Is there not a mysterious relationship between renunciation and joy, between sacrifice and magnanimity, between discipline and spiritual freedom?" 40

\subsection{The Third Death (Physical Death)}

The third death is the moment of separation of the soul from the body and the transition to eternity. As mentioned above - the man is born with the death. The threads of vitality and mortality intertwine in the life fabric from its very beginning. It is known that death "once, through sin, entered life and human nature" ${ }^{41}$. Accordingly, "death does not start with the death of the body. It started long ago, at the moment we took our first step into bodily existence. With dying, it starts to disappear."42 To be more specific, "in dying death leaves'(!) life. [...] By the death and resurrection of Christ human life is healed from death, and dying itself became the road where death leaves life, goes out of it - till the final separation of death from life - at the resurrection. " 43

The death that began at baptism and was radicalized through vows is now being completed. The passage through the third membrane becomes the final entrance to infinity. This is also predominance over death because death is overcome by effectuating eschaton "precisely there where its home is, where it appears to be strong — in the experience of death and mortality

roman_curia/congregations/ccscrlife/documents/rc_con_ccscrlife_doc_02021994_raternal-life-in-community_en.html (accessed: 19. VIII. 2017.)

38 VC, 85.

39 Cf. MILOSRDNE SESTRE SV. KRIŽA, Konstitucije i generalne odredbe, 50, in: MILOSRDNE SESTRE SV. KRIŽA, Uredbe za život Milosrdnih sestara svetoga Križa, Đakovo, 1987.

40 ET, 29.

41 Ante CRNČEVIĆ, Smrt: susret nade i spomena. O smrti, sprovodu i grobu, in: Živo vrelo, 32 (2016.) 11, 16.

42 Ibid.

43 Ibid. 
of the body " 44 . Death is overcome there where it resides - on the membrane. Finally, death is overcome "there where is dying with Christ and in Christ“"45.

$3 D$ transformation affirms Gennep's understanding of rites of passage and Bloch's idea of ritual death. Baptism and religious consecration are rites of initiation and undoubtedly belong to rites of passage. And, as it was said, according to Gennep, death is also one of rites of passage. In each of these rites is hidden ritual death. But 3D transformation also expands Gennep's and Bloch's ideas because while Gennep and Bloch were focused on rites, death in $3 D$ transformation is not understood only in terms of some specific ritual moments. In consecrated life, because of its ascetic dimension, death is something what transcends rite, it lasts not for a moment but whole life.

\section{Convents - Heavenly Embassies}

Understanding death as dynamic membrane instead of the impenetrable border and pointing out triple death-membrane in consecrated life in the light of its ascetic dimension allows further reflection on eschatological dimension of consecrated life. The anticipation of eschaton is so close to asceticism that is almost impossible talk about one dimension without another.

As it is mentioned previously, almost all the Church documents see the life of religious orders as anticipation of the heavenly kingdom, the prophetic announcement of the future wellbeing. Thus, in Lumen gentium we can read: "For the People of God has here no lasting city but seeks the city which is to come, and the religious state of life, in bestowing greater freedom from the cares of earthly existence on those who follow it, simultaneously reveals more clearly to all believers the heavenly goods which are already present in this age, witnessing to the new and eternal life which we have acquired through the redemptive work of Christ and preluding our future resurrection and the glory of the heavenly kingdom." 46 People of consecrated life become this way "the tangible seals which the Trinity impresses upon history so that people can sense with longing the attraction of divine beauty“" 47 .

Namely, living consecrated life means taking responsibility, an official way, in front of God and in front of the Church, to be alive sign of eschaton, to live on the membrane between time and eternity. In other words, the dying of the old man that began in the baptismal font continues on the

Ibid.

Joseph RATZINGER, Eshatologija. Smrt i vječni život, Split, 2016., 101.

LG, 44.

VC, 20 . 
membrane of daily life in a religious order, but in a much more visible and intensive way, liberating the space to inhabit eschaton. As it was previously mentioned, the whole reality of the consecrated life has got an eschatological sign. Due to the fact that religious communities have a specific form of life, convents are something like heavenly embassies, like parts of the heaven on earth, like ports of eternity. Consequently, consecrated people could be named as heavenly ambassadors.

\section{Conclusion}

In the contemporary cultural context, death is very often understood as impenetrable border where every kind of liveliness has no other choice but to give in. In the context of faith, death is rather a membrane which binds two worlds, temporal and eternal. The phenomenon of death in consecrated life could be reflected in ritual, physical and ascetic meaning. Ritual and physical death are in relation with three specific moments in consecrated life (baptism, religious consecration and physical death), the so-called $3 D$ transformation. Consecrated people, because of their ascetic-eschatological way of living are in permanent state of dying and that's why they are called to create membrane between heavenly eternity and temporal earth. Out of that reason, consecrated people could be named as heavenly ambassadors, and convents as heavenly embassy.

Since nowadays fewer and fewer young people decide to enter consecrated life, we need to ask ourselves: is this world still in need of heavenly ambassadors?! Does this world want within itself the membranes of eternity?! And, can this world exist without the membranes of eternity at all?! 
Abstract

\section{DEATH: BORDER OR MEMBRANE?}

Ascetic-eschatological Dimension of Consecrated Life as $3 D$ Transformation

This article discusses the ascetic-eschatological dimension of consecrated life through the lens of death. Death is not understood as an impenetrable border which separates the two worlds but as a fluid cell membrane which binds time and eternity. The phenomenon of death in consecrated life is perceived in three ritual events: baptism, religious consecration and physical death. These three moments make the so-called 3D (three deaths) transformation which is not only in these three events but through asceticism it is extended to the whole existence of the consecrated person.

Ascetic way of living is the membrane where eschaton transcends its own borders. The effort of asceticism and joy of eschaton in consecrated life are two sides of the same reality. Considering the relation between asceticism and eschaton, a convent could be named a heavenly embassy and consecrated people heavenly ambassadors.

KEY wORDS: border, consecrated life, convent, death, eschaton, membrane, 3D transformation 